Document downloaded from:

http://hdl.handle.net/10251/82185

This paper must be cited as:

Torres-Pérez, P.; Méndez-Rodríguez, E.; Orduña Malea, E. (2016). Mobile Web Adoption in Top Ranked University Libraries: A Preliminary Study. Journal of Academic Librarianship. 42(4):329-339. doi:10.1016/j.acalib.2016.05.011.

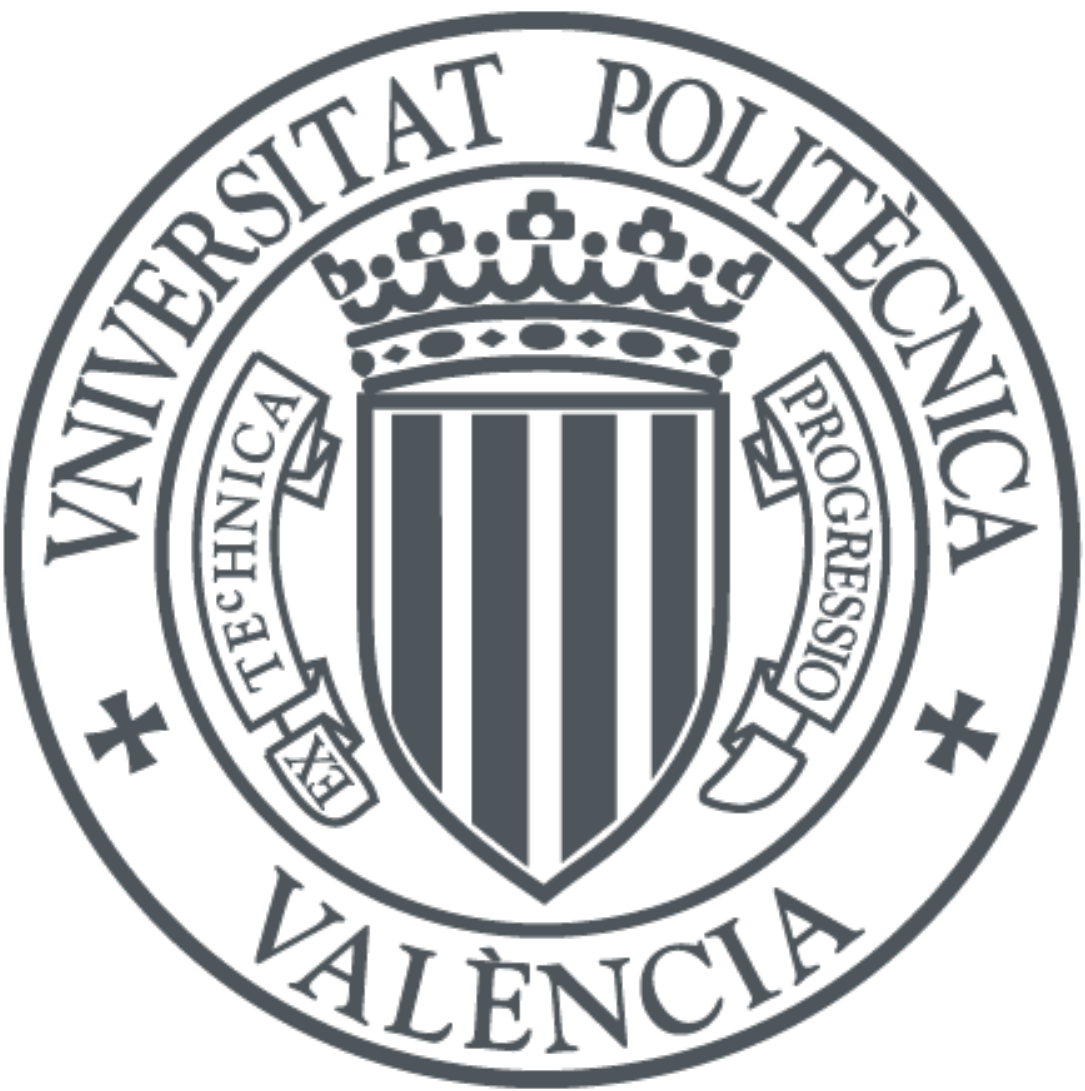

The final publication is available at

http://dx.doi.org/10.1016/j.acalib.2016.05.011

Copyright Elsevier

Additional Information 


\title{
Mobile Web Adoption in Top Ranked University Libraries: A Preliminary Study
}

\author{
Paula Torres-Pérez $^{1}$, Eva Méndez-Rodríguez ${ }^{2 *}$ and Enrique Orduna-Malea ${ }^{3}$ \\ ${ }^{1}$ Fundación MAPFRE. Documentation center. Bárbara de Braganza 14, 28004 Madrid (Spain). Email: \\ paulape@fundacionmapfre.org \\ ${ }^{2}$ Librarianship and Information Science Department. Universidad Carlos III de Madrid. Calle de Madrid \\ 128, Getafe 28903 (Spain). Email: emendez@bib.uc3m.es \\ ${ }^{3}$ EC3 Research Group. Polytechnic University of Valencia. Camino de Vera s/n, Valencia 46022 (Spain). \\ Email: enorma@upv.es \\ * Corresponding author
}

\begin{abstract}
:
This paper aims to study the level of adoption of mobile access to the academic libraries in the best universities in the world as well as the quality of services offered in order to ascertain if the quality of academic apps and mobile websites are at the level of the overall web impact of world-class universities. For the top 50 Universities according to the Ranking Web of Universities (2014), we determined whether there is a mobile website or app for their libraries. Finally we evaluated the services offered against a list of 14 indicators. The results show that $88 \%$ of the libraries studied (44) offer mobile access via Web or app, showing a high level of mobile adoption in elite universities. The form is clearly uneven: $80 \%$ (40) offer mobile web access while only 34\% (17) have an app. As to the content, no library offered all 14 points evaluated, and the results are varied. Only $50 \%$ of apps meet at least half the indicators. In the case of mobile web this figure improves notably to $74.3 \%$. We can note a high level of mobile web adoption in the world's best universities, although the quality does not reach their level of excellence.
\end{abstract}

Keywords:

Mobile applications; Apps; mobile web, Web Ranking of universities, university libraries. 


\section{Introduction}

Using web indicators to study the impact of universities (principally through analysis of university websites) provides extremely useful information. These indicators can provide detailed measures, sensitive to geographic, linguistic and cultural factors (Thelwall, 2004). Moreover the Web allows us to study the impact of a university's missions, not just those related to research (almost the sole measure in the main international rankings of universities (Aguillo, 2009). The Web permits us to consider teaching (in the form of open educational resources online), knowledge transfer (in the form of patents, university-business links) and other areas complementary or subsidiary to research (Kousha \& Thelwall, 2008; Thelwall \& Kousha, 2008).

Further, the entities for governance, administration and services can be quantified, making the website a complex system able to reflect legal and functional activities (Orduña-Malea \& Ontalba-Ruipérez, 2013). Among these entities are services responsible for the creation, diffusion and consumption of a significant amount of information, directed at students, professors and researchers. In particular we highlight academic libraries, a fundamental node to the transition to the electronic university (Lewis, 2015; Orduña-Malea \& Regazzi, 2013).

Given the functions of university libraries, including development, maintenance and distribution of information-rich products (catalogues, digital collections or institutional repositories), they should be one of the principal nodes of access from universities to the network. A priori, this should particularly be the case for universities who lead the international rankings (supposedly those with the best researchers, professors, students, services and infrastructure). It would be logical to expect that libraries in world-class universities should be the most technologically advanced, offering access to high quality scientific information through the Web to allow researchers access to the best information anywhere anytime, and receiving high web impact. This should reinforce the scientific production, and therefore the position in international rankings of these universities.

However, despite the high percentage of content that the academic library brings to the website of the university, its visibility is still low. The reasons are mainly two:

1) the technical problems with the information organization ; 2) because more and more information is generated outside the library website, relegating its principal function as indicated in the NMC Horizon Report 2012 (Johnson, Adams Becker and Cummins, 2012; Orduña-Malea \& Regazzi, 2014). This last circumstance suggests the need to consider new ways to generate interest in the library to make its resources more accessible and visible. Thus moving towards the mobile web and/or the use of apps is a fundamental step (Lippincott, 2010). Mobile devices are increasingly used to search for information and libraries cannot ignore the multiple benefits these devices bring their users (Arroyo, 2011; Hill, 2015; Murphy, 2010).

The university in general and the academic library in particular already offer information and services to their users through various web channels including virtual campus, discussion fora, news, email, etc. Nevertheless, creating a mobile website or 
developing an app can be a complementary means to offer users this information in a simpler faster way with greater flexibility.

Through its app or website, libraries can offer a personal account where one can consult loan information, reserve materials, and access other traditional library services. Equally, access to databases or documents can offer the great advantage of rapid access to information required at a given moment (Kroski, 2008). Thus the development of a mobile application should be an important part of access to the information held by the university library, permitting it to compete with external sources of information.

There is no doubt that the mobile websites of academic libraries can provide great value to both universities and their academic and research libraries. Measuring their content and services (and their visibility, use and quality) would also allow us to obtain indicators reflecting their impact on the Web, complementing the value of indicators from the non-mobile web, and demonstrating the online visibility of the academic library and its contribution to the academic website of the institution.

Nonetheless, the web impact measurement for mobile websites is complex, especially in the case of apps. For this reason, evaluating both contents generated and services offered by those mobile websites may serve as a useful proxy. In this sense we can assume that better mobile websites can potentially generate higher web impact, not only for the library but for the university. Therefore, we could expect to find a positive correlation between these variables (quality and web impact), especially if the top world-wide universities are considered.

Few studies have analyzed to date the characteristics or offerings of mobile web or apps for the world's top universities and their libraries. Highlights include some country-focused studies such as Aldrich, 2010, based on libraries and universities belonging to the Association of Research Libraries (ARL); Canuel \& Crichton, 2011, who focus in the Association of Universities and Colleges of Canada (AUCC); or Liu \& Briggs, 2015, who analyze the top 100 US universities based in the U.S. News \& World Report's national university rankings. Even so, the comparative evaluation of mobile web and app quality among the libraries of top worldwide universities is lacking, as is analysis of the relationship between their quality and web impact on the universities that host them. Thus the main goal of the present work is to ascertain if the quality of academic apps and mobile websites are at the level of the overall web impact of world-class universities.

The following specific objectives are proposed:

- Determine the level of adoption of apps and mobile websites in the libraries of world-class universities.

- Evaluate the quality of services offered through mobile websites and apps by those libraries.

- Rank university libraries by the quality of their apps and mobile websites.

- Compare the quality of university libraries' mobile websites and apps with the web impact of those universities, measured through web indicators. 


\section{State of the art}

"Mobile devices" are small computers with processors, limited memory and internet connection. They include smartphones, PDAs and tablets. The variety of devices available and the ability of users to adopt them and adapt them to their daily needs have led to rapid growth in their use.

Among mobile devices, smartphones lead in number of units sold. In 2013 estimates of sales exceed 1 billion, an increase of more than 300 million over 2012, with China the greatest buyer globally ( $26.5 \%$ of smartphones sold), more than 8 percent ahead of the USA since 2012. According to the whitepaper "2013 mobile future in focus", 54\% of the mobile audience in the USA use smartphones, principally for sending text messages, compared to the tablets whose major use is search. In Europe, adoption of mobile devices is led by Spain (66\%), followed by the UK (64\%) (Donovan, 2013; Fundación Telefónica, 2014; Idc, 2013).

The growth in sales and use of smartphones to access the internet brings with it an increasing use of apps. These applications have grown in popularity since 2008, when the main online application stores began operations: Google Play https://play.google.com and Appstore https://www.apple.com/itunes/charts/freeapps, each hosting around 1.3 million active apps in August 2014. Globally more than 1.2 billion people were estimated to use mobile apps globally at the end of 2012 (Portio Research Mobile Factbook, 2013)

\subsection{Mobile web versus apps}

A mobile website can be described as a version or adaptation of a website specifically created to work well on mobile devices, offering rapid download and respecting the screen sizes of devices to meet users' interaction expectations.

An app is a program developed to be installed in mobile devices, designed for use in a particular task or to offer a particular functionality. Apps aim to provide additional value over the mobile web, offering information and services with a single touch. Their immediacy, 24/7 availability and the privacy that a mobile telephone offers are their principal advantages.

When choosing to develop an app or adapt a website for mobile web, different factors need to be considered:

- The mobile web generally has the advantage that developing a single application correctly will make it available on all mobile devices, whereas apps need to be developed specifically for each Operating System, limiting the number of devices that can use them (Hu \& Meier, 2010).

- The advantage of building an app is that devices often have capabilities which are not available (or available later) to a web application (e.g., payment facilities). 


\subsection{Usability and accessibility of apps}

In the early days of the mobile web users preferred where possible a "normal" website rather than a parallel version developed for mobile, but as the usability and functionality (and cost) of mobile devices has improved, this tendency has changed (McCathieNevile, 2009). In January 2014, mobile apps have overtaken PC Internet usage in the US (CNN Money, 2014).

The main limitations of mobile devices are related to the screen size, the usability of the interface, battery consumption and the necessity to adapt content to the mobile web or an app (Hernández-García, Iglesias-Pradas, Chaparro-Peláez, \& Pascual-Miguel, 2009). Further the use of any mobile website or app in a smartphone varies according to the characteristics of the device itself. It is therefore important to take into account the Operating System(s) with which to work (iOS, Android, Blackberry, Windows, etc.) as well as different screen sizes which can alter the visualization and optimal user interaction.

\subsection{Mobile Services in academia: universities and libraries}

Websites and apps help provide services related to teaching and research, key to the learning processes of students and professors (Kroski, 2008). The NMC Horizon Report 2012 identifies apps as part of the near-term horizon in superior education, a theme repeated in the 2014 report (Johnson, L., Adams Becker, S. and Cummins, 2012; Johnson, Adams Becker, Estrada, \& Freeman, 2014). Yet adoption in universities and their libraries is slow. According to "Mobile connections to libraries", only $13 \%$ of youth over 16 has accessed a library via a mobile device, increasing to $18 \%$ if the age range is focused to 18-29 - the normal age of university students (Rainie, 2012). Thus Jensen suggests that while mobile technology is very attractive in commercial or entertainment applications, it is perceived differently in the field of education, necessitating deeper analysis on the part of universities and libraries (Jensen, 2010).

The first universities to launch mobile versions were Massachusetts Institute of Technology (MIT) and Stanford University, in June and October 2008 respectively, when the adoption of smartphones by students was still low (Aldrich, 2010; Wilson \& McCarthy, 2010). The studies of mobile websites in universities and libraries carried out since then had been focused on design and description of service both in general and specific aspects such as usability and accessibility or identifying trends (Abarca Villoldo, Lloret Salom, Pons Chaigneau, Rubio Montero, \& Vallés Navarro, 2012; Arroyo Vázquez, 2015; Arroyo, 2011; Kroski, 2008; Lippincott, 2010; McKlernan, 2010; Paterson \& Low, 2011).

In parallel, analysis emerged focused on case studies, such as the pioneering study by Mills on the role of libraries at the University of Cambridge. This study includes web services, identifying the principal services necessary for users in this environment: Opening hours, library catalog, map of the library, and contact information (Mills, 2009). Also relevant is the report of Seeholzer and Salem, identifying the services that Kent State University Library users want to access through their smartphones, 
highlighting services related to finding scientific information (Seeholzer \& Salem, 2011). The different results of these two studies confirm the influence of the environment (type of university) on user needs. Linguistic and cultural difference are equally evident as seen in work done in China or Spain, countries with a high rate of mobile web adoption (Li, 2013; Merlo Vega, 2012; Shuiqing, 2008; Xiaoyan, Yam; Mingyang, 2010).

In terms of work analyzing large samples of universities or libraries, special attention should be paid to the seminal study of Aldrich who analyzed through a set of 22 indicators the mobile web versions of the 111 universities (and their libraries) belonging to the ARL (Association of Research Libraries) (Aldrich, 2010). The results showed that at the time of the study only 39 universities offered mobile access, and only 14 had mobile access to their libraries, with opening hours, location information and access to the catalogue most commonly available. Later, Canuel and Crichton analyzed the 95 academic libraries belonging to the AUCC (Association of Universities and Colleges of Canada). The authors only found a mobile version in 13 of them (Canuel \& Crichton, 2011)..

Recently, Liu and Briggs analyzed the top 100 university libraries' mobile services (based on the U.S. News \& World Report) through in-depth website visits and survey questionnaires. Nonetheless, this study is focused only on the United States and does not attempt to measure the online visibility of the mobile websites, instead describing the state of mobile services among US academic libraries and the experiences of these libraries (Liu \& Briggs, 2015).

Given the pace at which this technology evolves, there is a lack of recent study covering the best universities world-wide. There is a need not only to measure the existence, but the quality of mobile access and what it brings to the university in question, which is the focus of the this study.

\section{Methodology}

The method can by divided into the following steps: sample gathering, sample evaluation, and statistical analysis.

\section{Sample gathering}

The first step consisted of the selection of the world-class universities to comprise the sample for the analysis. To do this, we began with the selection of the 50 top universities according to the Web Ranking of Universities (Webometrics, July 2014 edition), produced since 2004 by the Cybermetrics Lab (Laboratorio de Cibermetría) of the Spanish National Research Council (CSIC) (http://webometrics.info). This ranking is devoted to the analysis of universities' websites in order to get insights regarding to their overall web impact through the application of four indicators (Presence, Impact, Openness, and Excellence). These 50 universities, with their corresponding indicators, are given in Appendix I, where the scope of each indicator is offered as well. The ranking of universities was chosen instead of possible alternatives such as ARWUShanghai, THE (Times Higher Education), QS Ranking, Leiden Ranking, etc. because it is based on web indicators (especially Presence, Impact and Openness), thus allowing 
measurement not only of academic excellence but also innovation and policies for use of new technology on a global scale (I. F. Aguillo, Granadino, Ortega, \& Prieto, 2006). Mobile websites and apps offer access to large amounts of web information and imply the adoptions of new technologies by the universities.

Next, for the 50 universities chosen, we identified the mobile websites and apps of their libraries, and determined whether these were independent of, or formed part of, the institutional web presence of the university as a whole. This information generally came directly from the sites of the universities. When it was impossible, direct communication with the institutions through email, chat, or online reference services such as "Ask a librarian" were used to get the necessary information.

\section{Sample evaluation}

The second step consisted in the evaluation of each mobile website or app identified in the previous step, assessing which services, functionality or information they provided. For this purpose, we designed an evaluation model composed of 14 indicators (Table 1 ), based basically on the combination and an update to the models already proposed by (Aldrich, 2010; Méndez Rodríguez, 1999; Paterson \& Low, 2011).

Table 1. App/mobile web evaluation model

\begin{tabular}{ll}
\hline REF & INDICATOR \\
\hline 01 & Library hours \\
02 & Library directory \\
03 & Library catalog \\
04 & Contact us \\
05 & Main library \\
06 & Ask a librarian \\
07 & Library news \\
08 & Renew material \\
09 & My account \\
10 & Computer availability \\
11 & Floor plans/maps \\
12 & Databases \\
13 & Loan periods \\
14 & Reserve study \\
\hline
\end{tabular}

The evaluation of each mobile website or app consisted in determining the existence of each service, such that presence of a given service counted for one point toward a score (for a possible maximum of 14 points). This evaluation was done in August 2014.

\section{Statistical analysis}

The scores obtained for each mobile website and/or app through the application of the evaluation model were uploaded to a spreadsheet to be statistically analyzed. Finally, in order to compare the quality of the mobile website/app with the web impact of each 
university, we compared the score of each mobile website/app to their position in the Web Ranking of Universities through the coefficient of correlation of Pearson ( $\alpha=0.1$ ).

\section{Results}

\subsection{Level and type of adoption of the mobile web}

Eighty percent of universities studied (40) have a mobile website for their library (the URLs are in Appendix II). However, only 34\% (17 universities) have an app, while in $26 \%$ (13) a mobile version and an app coexist. Of the apps, in seven universities they are available both for iOS and Android, while nine only have iOS apps and in one (Utrecht University), there is only a version for Android.

Figure 1 shows the distribution of mobile websites for the 50 universities studied, by type of presence offered (mobile web, app, both, neither).

Figure 1. Distribution of academic libraries by type of presence

As seen in Figure 1, in the category "Mobile web" we have included cases where the web of the library is navigable with a mobile device (responsive design), but without a specific mobile website nor app. These universities are the University of Washington and the University of Minnesota. Meanwhile, in as many as six universities there is neither a mobile version nor app for the library, and the website is not designed to facilitate navigation on a mobile device. Those universities are: New York University, Pekin University, Purdue University, Stanford University, Tsinghua University China and University of Sao Paulo.

Finally, we tested whether the mobile web or app of the library was independent or integrated into the university's mobile web presence. The data (Figure 2) show different results according to the type of presence (mobile web or app). The complete data by university are available in Appendix III. 
Figure 2. Integration of the Libraries' mobile web presence

For libraries with a mobile website in figure 2 we see the majority $(32 ; 64 \%)$ maintain a web presence independent of the university, while in only 3 universities (Harvard University, MIT and University of Oxford) is the library's presence integrated in the mobile web space of the host institution.

With apps the opposite occurs, with 14 of the 16 libraries' apps integrated in the university's app, while only two (University of Southern California and Utrecht University) are independent. In the case of the National Taiwan University we found a mobile website as well as an app, although the latter was in beta when we were carrying out the study and could not be evaluated. So, the results of this university have been removed from Figure 2.

Finally we highlight a special category of four universities (Princeton University, University of California-San Diego, University of Pittsburgh and University of Southern California), where an independent mobile website lives alongside one integrated into the university's.

\subsection{Evaluation of services}

Figure 3 shows the level of implementation for each mobile web service of the 14 proposed in Table 1 . We can see that, surprisingly, none of the 14 services are offered by $100 \%$ of the libraries evaluated. 
Figure 3. Services provided by apps or mobile web in the libraries evaluated $(n=50)$

For mobile websites $(n=40)$, the services available in most libraries are "Library hours" (36), "Contact us" (33) and "Main Library" and "Floor maps" (both in 28 libraries). On the other hand, "Renew material" (10) and "Loan periods" (6) are by a large margin the services least offered in the libraries analyzed.

For apps ( $n=17)$, the services implemented most are "Library hours" and "Floor plans" (12 each), followed by "Library catalog", present in 11 apps. "Computer availability" and "Loan periods" are the least implemented (each by only 2 universities).

Despite notable differences between app and mobile web versions, (for example the use of geolocalization to generate maps, or access to the catalog are better in apps, while information about the library or its databases is better in mobile websites), the correlation between the two is significant $(r=.7 ; \alpha=0.5)$.

\subsection{Ranking by services (apps and mobile web)}

Here we evaluate the offering of services for each university. The complete data for apps and mobile web is available in Appendix IV. The top ten universities by number of services included in the library's app is shown in Table 2 (The complete ranking is available in Appendix V).

Table 2. Top 10 Academic Library ranking according to app services deployed

\begin{tabular}{llr}
\hline RANK & \multicolumn{1}{c}{ UNIVERSITY } & APP SCORE \\
\hline $\mathbf{1}$ & University of Washington & 13 \\
$\mathbf{2}$ & University of Illinois-Urbana Champaign & 10 \\
$\mathbf{3}$ & Harvard University & 9 \\
$\mathbf{3}$ & Massachusetts Institute of Technology & 9 \\
\hline
\end{tabular}




\begin{tabular}{lll}
\hline $\mathbf{5}$ & University of California-Berkeley & 8 \\
$\mathbf{6}$ & Columbia University New York & 7 \\
$\mathbf{6}$ & Texas A\&M University & 7 \\
$\mathbf{6}$ & University of Toronto & 7 \\
$\mathbf{9}$ & University of California-Los Angeles UCLA & 6 \\
$\mathbf{9}$ & University of Chicago & 6 \\
\hline
\end{tabular}

The University of Washington tops the ranking (13 services). Curiously, the only service of the 14 examined that is not included is "Floor maps/plans", one of the most common for apps in the sample. In second place is the University of Illinois-Urbana Champaign (10) with Harvard University and MIT third (9 services each).

The top ten universities by number of services included in the mobile web version of the library is shown in Table 3 (the complete ranking is available in Appendix VI).

Table 3. Academic Library ranking by mobile web services deployed

\begin{tabular}{llc}
\hline RANK & \multicolumn{1}{c}{ UNIVERSITY } & MOBILE SCORE \\
\hline 1 & University of Minnesota & $\mathbf{1 3}$ \\
1 & University of Washington & $\mathbf{1 3}$ \\
3 & University of Southern California & $\mathbf{1 2}$ \\
4 & University of British Columbia & $\mathbf{1 1}$ \\
4 & University of Maryland & $\mathbf{1 1}$ \\
4 & University of Wisconsin Madison & $\mathbf{1 1}$ \\
7 & Cornell University & $\mathbf{1 0}$ \\
7 & University of Illinois-Urbana Champaign & $\mathbf{1 0}$ \\
7 & Yale University & $\mathbf{1 0}$ \\
10 & Duke University & $\mathbf{9}$ \\
10 & Harvard University & $\mathbf{9}$ \\
10 & Massachusetts Institute of Technology & $\mathbf{9}$ \\
10 & Michigan State University & $\mathbf{9}$ \\
10 & Princeton University & $\mathbf{9}$ \\
10 & University of Virginia & $\mathbf{9}$ \\
10 & Utrecht University & $\mathbf{9}$ \\
\hline
\end{tabular}

The University of Washington is again in first position with the same score as its app (offering the same services), this time tied with the University of Minnesota, which despite having pioneered other Internet technologies (gopher), offers no app. In third place is the University of Southern California (12), whose app was among the lowest scoring (offering only 5 services). This difference between the score of an app and the mobile web for the same university shows inequality in their development. If we consider the 13 universities who developed both an app and a mobile web, the correlation of rankings is low $(r=.46)$.

Finally, comparing the positions of universities in the two rankings generated (Appendix V and $\mathrm{VI}$ ) with their positions in the Web Ranking of Universities (WR), we again see divergence between mobile websites and apps. On one hand there is a significant positive correlation between the ranking of library apps and the global position of the universities in the WR $(r=.77)$, although there are particular cases where this does not apply, especially the University of Illinois-Urbana Champaign (second in 
the apps ranking, but $22^{\text {nd }}$ in the WR) or the University of Chicago (ranked ninth for apps, $39^{\text {th }}$ in the WR). If the WR positions are standardized from 1 to 16 (in order to compare with the same range of apps), the correlation obtained is similar $(r=.73 ; \alpha=0.1)$. On the other hand the results for mobile websites show a lack of correlation $(r=.23)$. If the WR positions are standardized from 1 to 40 (in order to compare with the same range of mobile websites), the correlation obtained is similar ( $r=.24 ; \alpha=0.1$ ).

\section{Discussion}

These results should be treated with caution, for reasons we shall discuss here.

Bias of the sample

Of the universities considered (Top 50), we find 37 in the US, only 3 in the UK, 2 from Canada and China and 1 each from Brazil, South Korea, Switzerland, Taiwan, Holland and Finland. The leadership of US universities in the rankings could bias the sample. A greater sample that showed the situation clearly for other countries would be interesting, although the fundamental goal of this study was to consider only the world's universities irrespective of nationality.

\section{Change and obsolescence}

The functionality of mobile websites can change very rapidly, as does the technology. Hence this study should be considered as a snapshot reflecting the adoption of mobile website and apps by libraries of the world's best universities at a given moment (August 2014).

\section{Evaluation model}

The evaluation model used considers 14 principal functionalities that should be present in a library's mobile website or app. Thus the results partially concur with those previously obtained by Mills, Aldrich, and Liu and Briggs (Aldrich, 2010; Liu \& Briggs, 2015; Mills, 2009). However in the future it would be desirable to consider new indicators, enriching the model and adapting it to new services which may appear.

\section{Weighting of indicators}

The scoring in this study does not consider differences between indicators, although some services are probably more important than others. Accordingly, it would be possible to provide a system of weighting. However the purpose of this study was merely to examine the existence or absence of basic functionality.

\section{Distinct natures and correlations}

Finally the correlations observed should be treated cautiously, given that the indicators used are of distinct natures, and the sample sizes are different (17 apps and 40 mobile websites of the 50 universities analyzed).

\section{Conclusions}

A good proportion of the university libraries studied $88 \%$ (44) are accessible through mobile devices (through an app or mobile web), showing a high level of mobile web 
adoption in universities. The form of adoption varies: $80 \%(40)$ of the libraries studied provide access through a mobile website while only $34 \%$ (17) offer an app, showing the development of apps is yet to be widespread in this area. It is hard to determine why universities have not implemented apps, especially in the cases studied (institutions of recognised prestige with no apparent problem developing the technology).

The integration of content appears to depend on the form adopted. Libraries' mobile webs tend to be independent of the university's institutional mobile web (as seen in $82 \%$ of cases), while libraries' apps are generally integrated into that of the university (87.5\% of apps analyzed). We consider the integration positive, as users should have a single app offering access to all the information the university provides, including the library, rather than one for each possible service.

Regarding evaluation of the content, no library provided all 14 services, and the results are quite varied. Fifty percent of apps show less than half the indicators met (i.e. offer fewer than 7 services). This figure improves for mobile websites, with $74.3 \%$ offering at least half.

As for the services these apps and mobile webs provide, we can conclude that among the most common are those giving information about library opening hours, although certain services are likely to be offered depending on whether the library has a mobile website (e.g. contact information or information about the library) or app (e.g. catalog access, geolocalization).

Among the least common services are loan information and renewals. Equally notable is the scarcity of information about user accounts, perhaps due to possible security issues.

We found the following limitations in services offered:

\section{Difficulty locating resource}

It is difficult to find, from the website of the library, an app or mobile website, as the pages do not give this information. Some sites have a banner identifying the availability of an app or mobile website, leading to information about the possibliities they offer. On other occasions, it was necessary to resort to virtual information sources, or email, which gave immediate results.

\section{Lack of connection to social networks}

Although the majority of libraries studied have profiles in social networks (Facebook, Twitter, Youtube, etc.), these are independent of apps and mobile webs, which offer no, or very limited, access to that social media presence. The ability to link a social media profile with the different profiles of the library could provide a collaboration tool enabling users to continue interchanging information without needing to leave the library's app or mobile website, although certain problems with the privacy of content may limit such development. 
Most apps are only available for iOS (52.9\% of apps analyzed). But if the university library wants to offer services to all, access should be available to users of other operating systems (principally Android and Windows). Equally important is that apps are also useful on tablets. The preponderant development of iOS apps could be the reason many universities opt for device adaptation or responsive design in place of apps.

Lastly, the position of universities in the Web Ranking of Universities bears no apparent relation to how many services their libraries' mobile web provides. Yet there is a significant correlation in the case of apps, albeit from a much smaller sample. Increasing the sample size would allow more accurate results.

As a final conclusion, a high level of mobile web adoption in the world's best universities is notable, although the quality does not reach the general level of excellence of these institutions. We consider the inclusion of the library in universities' apps as critical, showing the importance these institutions give to the academic library and enhancing its use for teaching and research. We therefore consider the current level of adoption (as of 2014) low.

The results of this study have demonstrated that the quality of university libraries' mobile websites does not correlate with the overall web impact of the universities. For this reason, advancement in the direct measurement of mobile websites' impact is needed. Not only to get complementary insights about the quality of these mobile websites, but also to better quantify their contribution on the web presence as well as the visibility of the university (an important issue in the development of web strategies and policies both for the library and the university).

The evaluation model proposed in this research would serve as a base for future quantitative studies of mobile websites in universities and their libraries since they will provide useful service patterns and benchmark suitable for the improvement of academic libraries' mobile web services. The incorporation of pure web indicators (e.g. web presence, visibility or usage) in the model would be necessary. The current trend towards responsive design for websites may help in the design and incorporation of such web metrics. 


\section{References}

[All the electronic references were last accessed on 15 March 2016.]

Abarca Villoldo, M., Lloret Salom, A., Pons Chaigneau, D. M., Rubio Montero, F. J., \& Vallés Navarro, R. (2012). Tecnologías móviles en bibliotecas : aplicaciones en la biblioteca de la Universitat Politècnica de València. Retrieved from http://riunet.upv.es/handle/10251/14793

Aguillo, I. (2009). Measuring the institution's footprint in the web. Library Hi Tech, 27(4), 540556. http://doi.org/10.1108/073788309

Aguillo, I. F., Granadino, B., Ortega, J. L., \& Prieto, J. A. (2006). Scientific research activity and communication measured with cybermetrics indicators. Journal of the American Society for Information Science and Technology, 57(10), 1296-1302. http://doi.org/10.1002/asi.20433

Aldrich, A. W. (2010). Universities and Libraries Move to the Mobile Web. EDUCAUSE Quarterly, 33(2). Retrieved from http://www.educause.edu/EDUCAUSE+Quarterly/EDUCAUSEQuarterlyMagazineVolum/U niversitiesandLibrariesMoveto/206531

Arroyo Vázquez, N. (2015). Tecnología móvil y bibliotecas en 2014: ampliando el concepto de movilidad. In I. Baiget, Tomás; Olea (Ed.), Anuario Think EPI 2015. Informes ThinkEPI sobre documentación y comunicación.

Arroyo, N. (2011). Información en el móvil. (UOC, Ed.). Barcelona.

Canuel, R., \& Crichton, C. (2011). Canadian academic libraries and the mobile web. New Library World, 112(3/4), 107-120. http://doi.org/10.1108/03074801111117014

CNN Money. (2014). Mobile apps overtake PC Internet usage in U.S. CNN Money. Retrieved from http://money.cnn.com/2014/02/28/technology/mobile/mobile-apps-internet

Donovan, M. (2013). Comscore, 2013 mobile future in focus. Annals of neurology (Vol. 73). Retrieved from http://www.comscore.com/Insights/Presentations-andWhitepapers/2013/2013-Mobile-Future-in-Focus2

Fundación Telefónica. (2014). La Sociedad de la Información en España 2013. Fundacion telefónica. Retrieved from http://www.fundaciontelefonica.com/arte_cultura/publicaciones-listado/pagina-itempublicaciones/?itempubli=261

Hernández-García, Á., Iglesias-Pradas, S., Chaparro-Peláez, J., \& Pascual-Miguel, F.-J. (2009). La Web en el móvil: tecnologías y problemática. El Profesional de La Informacion, 18(2), 137144. http://doi.org/10.3145/epi.2009.mar.03

Hill, K. (2015). Mobile Devices: A Practical Guide for Librarians. Australian Academic \& Research Libraries, 46(4), 315-315. http://doi.org/10.1080/00048623.2015.1109016

Hu, R., \& Meier, A. (2010). Mobile Strategy Report: Mobile Device User Research. Strategy. Retrieved from http://www.cdlib.org/services/uxdesign/docs/CDL_Mobile_Device_User_Research_final. pdf

Idc. (2013). Worldwide Quarterly Smart Connected Device Tracker. Retrieved from IDC Worldwide Quarterly Smart connected device tracker

Jensen, R. B. (2010). Optimizing library content for mobile phones. Library Hi Tech News, 27(2), 6-9. http://doi.org/10.1108/07419051011050411 
Johnson, L. , Adams Becker, S. and Cummins, M. (2012). The NMC Horizon Report: 2012 Higher Education Edition. Retrieved from http://www.nmc.org/pdf/2012-horizon-report-HE.pdf

Johnson, L., Adams Becker, S., Estrada, V., \& Freeman, A. (2014). NMC Horizon Report: 2014 Library Edition. Retrieved from http://cdn.nmc.org/media/2014-nmc-horizon-reportlibrary-EN.pdf

Kousha, K., \& Thelwall, M. (2008). Assessing the impact of disciplinary research on teaching: An automatic analysis of online syllabuses. Journal of the American Society for Information Science and Technology, 59(13), 2060-2069. http://doi.org/10.1002/asi.20920

Kroski, E. (2008). On the Move with the Mobile Web: Libraries and Mobile Technologies. October (Vol. 44). Retrieved from http://eprints.rclis.org/15024/1/mobile_web_Itr.pdf

Lewis, D. W. (2015). Inventing the Electronic University. College \& Research Libraries, 76(3), 296-309. http://doi.org/10.5860/crl.76.3.296

Li, A. (2013). Mobile Library Service in Key Chinese Academic Libraries. Journal of Academic Librarianship, 39(3), 223-226. http://doi.org/10.1016/j.acalib.2013.01.009

Lippincott, J. K. (2010). A mobile future for academic libraries. Reference Services Review, 38(2), 205-213. http://doi.org/10.1108/00907321011044981

Liu, Y. Q., \& Briggs, S. (2015). A Library in the Palm of Your Hand: Mobile Services in Top 100 University Libraries. Information Technology and Libraries, 34(2). http://doi.org/10.6017/ital.v34i2.5650

McCathieNevile, C. (2009). Movilizando la Web: dónde y cómo vamos hacia una Web móvil. El Profesional de La Informacion, 18(2), 121-128. http://doi.org/10.3145/epi.2009.mar.01

McKlernan, G. (2010). Worldwide Mobile Phone Adoption and Libraries. Searcher, 18(3), 48. Retrieved from http://proquest.umi.com/pqdweb?did=2009125071\&Fmt=7\&clientld=109526\&RQT=309 \&VName $=P Q D$

Méndez Rodríguez, E. M. (1999). Las bibliotecas públicas españolas en la Web: ¿qué información ofrecen nuestras bibliotecas públicas en la Red? Educación Y Biblioteca, 11(106), 48-54. Retrieved from http://dialnet.unirioja.es/servlet/articulo?codigo=127153\&orden=342350\&info=link $\backslash$ nhtt p://dialnet.unirioja.es/servlet/extart?codigo $=127153$

Merlo Vega, J. A. (2012). Biblio USAL. La primera aplicación de bibliotecas nativa para dispositivos móviles realizada en España. Mi Biblioteca, 8(29), 54-60. Retrieved from http://gredos.usal.es/jspui/bitstream/10366/115738/1/DBD_Merlo_BiblioUSAL.pdf

Mills, K. (2009). M-Libraries: Information use on the move. Retrieved from https://www.repository.cam.ac.uk/handle/1810/221923

Murphy, J. (2010). Using Mobile Devices for Research: Smartphones, Databases and Libraries. Online, 34(3), 14-18. Retrieved from https://www.questia.com/magazine/1P32037037881/using-mobile-devices-for-research-smartphones-databases

Orduña-Malea, E., \& Ontalba-Ruipérez, J. A. (2013). Proposal for a multilevel university cybermetric analysis model. Scientometrics, 95(3), 863-884. http://doi.org/10.1007/s11192-012-0868-5

Orduña-Malea, E., \& Regazzi, J. (2013). Influence of the Academic Library on US University Reputation: A Webometric Approach. Technologies, 1(2), 26-43. http://doi.org/10.3390/technologies1020026

Orduña-Malea, E., \& Regazzi, J. J. (2014). U.S. academic libraries: Understanding their web 
presence and their relationship with economic indicators. Scientometrics, 98(1), 315-336. http://doi.org/10.1007/s11192-013-1001-0

Paterson, L., \& Low, B. (2011). Student attitudes towards mobile library services for smartphones. Library Hi Tech, 29(3), 412-423. http://doi.org/10.1108/07378831111174387

Portio Research Mobile Factbook 2013. (2013). Retrieved from http://www.portioresearch.com/media/3986/Portio Research Mobile Factbook 2013.pdf

Rainie, L. (2012). Mobile Connections to Libraries devices. Retrieved from http://libraries.pewinternet.org/2012/12/31/mobile-connections-to-libraries

Seeholzer, J., \& Salem, J. A. (2011). Library on the Go: A Focus Group Study of the Mobile Web and the Academic Library. College \& Research Libraries, 72(1), 9-20. http://doi.org/10.5860/crl-65r1

Shuiqing, M. (2008). The Rise and Development of Mobile Library Services. Journal of Academic Libraries, 1(1), 3-6. Retrieved from http://en.cnki.com.cn/Article_en/CJFDTOTALDXTS200801001.htm

Thelwall, M. (2004). Link analysis: an information science approach. London: Academic Press. Retrieved from http://linkanalysis.wlv.ac.uk/index.html

Thelwall, M., \& Kousha, K. (2008). Online presentations as a source of scientific impact? An analysis of PowerPoint files citing academic journals. Journal of the American Society for Information Science and Technology, 59(5), 805-815. http://doi.org/10.1002/asi.20803

Wilson, S., \& McCarthy, G. (2010). The mobile university: from the library to the campus. Reference Services Review, 38(2), 214-232. http://doi.org/10.1108/00907321011044990

Xiaoyan, Yam; Mingyang, L. (2010). Research of Actuality of Mobile-based Information Service in Libraries of China. Researches in Library Science, 2(1). Retrieved from http://en.cnki.com.cn/Article_en/CJFDTOTAL-TSSS201002019.htm 
Appendix A. Top 50 Universities according to Ranking Web of Universities (July 2014 Edition)

\begin{tabular}{|c|c|c|c|c|c|c|}
\hline $\mathbf{R}$ & UNIVERSITY & URL & Presence & Impact & Openness & Excellence \\
\hline 1 & Harvard University & harvard.edu & 10 & 1 & 1 & 1 \\
\hline 2 & Massachusetts Institute of Technology & mit.edu & 5 & 1 & 27 & 14 \\
\hline 3 & Stanford University & stanford.edu & 2 & 3 & 52 & 3 \\
\hline 4 & Cornell University & cornell.edu & 24 & 5 & 67 & 20 \\
\hline 5 & University of Michigan & umich.edu & 37 & 7 & 59 & 5 \\
\hline 6 & University of California Berkeley & berkeley.edu & 40 & 4 & 178 & 15 \\
\hline 7 & Columbia University New York & washington.edu & 60 & 6 & 141 & 12 \\
\hline 7 & University of Washington & washington.edu & 25 & 10 & 113 & 6 \\
\hline 9 & University of Minnesota & umn.edu & 110 & 9 & 15 & 23 \\
\hline 10 & University of Pennsylvania & upenn.edu & 42 & 11 & 109 & 9 \\
\hline 11 & University of Texas Austin & utexas.edu & 118 & 8 & 43 & 51 \\
\hline 12 & University of Wisconsin Madison & wisc.edu & 9 & 18 & 194 & 21 \\
\hline 13 & Pennsylvania State University & psu.edu & 78 & 13 & 53 & 36 \\
\hline 14 & University of California Los Angeles UCLA & ucla.edu & 64 & 17 & 317 & 4 \\
\hline 15 & University of Toronto & utoronto.ca & 33 & 38 & 51 & 7 \\
\hline 16 & Yale University & yale.edu & 41 & 12 & 343 & 19 \\
\hline 17 & University of Oxford & ox.ac.uk & 39 & 21 & 295 & 8 \\
\hline 18 & University of Cambridge & cam.ac.uk & 21 & 20 & 311 & 10 \\
\hline 19 & Purdue University & purdue.edu & 99 & 16 & 45 & 87 \\
\hline 20 & Texas A\&M University & tamu.edu & 19 & 30 & 41 & 89 \\
\hline 21 & University of British Columbia & ubc.ca & 127 & 40 & 24 & 24 \\
\hline 22 & University of Illinois Urbana Champaign & http:illinois.edu & 4 & 58 & 56 & 43 \\
\hline 23 & Michigan State University & msu.edu & 31 & 14 & 339 & 93 \\
\hline 24 & New York University & nyu.edu & 132 & 15 & 344 & 44 \\
\hline 25 & Johns Hopkins University & jhu.edu & 45 & 50 & 631 & 2 \\
\hline 26 & University of Florida & ufl.edu & 76 & 26 & 180 & 40 \\
\hline 27 & Princeton University & princeton.edu & 34 & 19 & 398 & 76 \\
\hline 28 & Swiss Federal Institute of Technology Zurich & ethz.ch & 83 & 42 & 81 & 31 \\
\hline 29 & Universidade de São Paulo USP & usp.br & 48 & 63 & 6 & 81 \\
\hline 30 & Duke University & duke.edu & 223 & 35 & 219 & 17 \\
\hline 31 & University of California San Diego & ucsd.edu & 163 & 29 & 451 & 13 \\
\hline 32 & California Institute of Technology Caltech & caltech.edu & 17 & 66 & 125 & 34 \\
\hline 33 & University of Maryland & umd.edu & 65 & 37 & 112 & 70 \\
\hline 34 & Seoul National University & snu.ac.kr & 36 & 32 & 255 & 79 \\
\hline 35 & National Taiwan University & ntu.edu.tw & 15 & 81 & 12 & 103 \\
\hline 36 & University of North Carolina Chapel Hill & unc.edu & 141 & 25 & 511 & 27 \\
\hline 37 & Peking University & pku.edu.cn & 93 & 44 & 148 & 49 \\
\hline 38 & University College London & ucl.ac.uk & 308 & 64 & 100 & 11 \\
\hline 39 & University of Chicago & uchicago.edu & 111 & 23 & 558 & 46 \\
\hline 40 & University of Pittsburgh & pitt.edu & 344 & 59 & 69 & 28 \\
\hline 41 & Utrecht University & uu.nl & 67 & 105 & 26 & 30 \\
\hline 42 & Ohio State University & osu.edu & 183 & 56 & 132 & 33 \\
\hline 43 & Carnegie Mellon University & cmu.edu & 90 & 22 & 179 & 160 \\
\hline 44 & University of Arizona & arizona.edu & 227 & 27 & 327 & 69 \\
\hline 45 & University of Helsinki & helsinki.fi & 35 & 112 & 5 & 101 \\
\hline 46 & University of Virginia & virginia.edu & 18 & 28 & 833 & 95 \\
\hline 47 & Georgia Institute of Technology & gatech.edu & 85 & 60 & 94 & 83 \\
\hline 48 & Tsinghua University China & tsinghua.edu.cn & 378 & 41 & 174 & 45 \\
\hline 49 & University of Southern California & usc.edu & 327 & 24 & 456 & 56 \\
\hline 50 & University of California Davis & ucdavis.edu & 229 & 43 & 448 & 29 \\
\hline
\end{tabular}


IMPACT: The indicator is the product of square root of the number of backlinks and the number of domains originating those backlinks. The link visibility data is collected from the two most important providers of this information: Majestic SEO and Ahrefs.

PRESENCE: The total number of web pages hosted in the main web domain (including all the subdomains and directories) of the university as indexed by the largest commercial search engine (Google).

OPENNESS: This indicator takes into account the number of rich files (pdf, doc, docx, ppt) published in dedicated websites according to the academic search engine Google Scholar. The objective is to consider recent publications (currently those published between 2008 and 2012).

EXCELLENCE: The university scientific output being part of the $10 \%$ most cited papers in their respective scientific fields. Data collected from Scopus. 
Appendix B. Mobile URL

\begin{tabular}{|c|c|c|}
\hline & UNIVERSITY & MOBILE URL \\
\hline 1 & Bibliotecas da Universidade de São Paulo USP & -- \\
\hline 2 & California Institute of Technology Caltech Library & library.caltech.edu/m/ \\
\hline 3 & Carnegie Mellon University Libraries & m.library.cmu.edu/ \\
\hline 4 & Columbia University New York & m.library.columbia.edu/ \\
\hline 5 & Cornell University Libraries & m.mannlib.cornell.edu/ \\
\hline 6 & Duke University Libraries & m.duke.edu \\
\hline 7 & Georgia Institute of Technology Library & m.library.gatech.edu/ \\
\hline 8 & Harvard University Library & m.harvard.edu \\
\hline 9 & * Johns Hopkins University & webapps.jhu.edu/jhuniverse/academics/libraries/ \\
\hline 10 & * Massachusetts Institute of Technology Libraries & libraries.mit.edu \\
\hline 11 & Michigan State University Library & m.lib.msu.edu/ \\
\hline 12 & National Taiwan University Library & mobile.lib.ntu.edu.tw \\
\hline 13 & New York University Libraries & -- \\
\hline 14 & Ohio State University Libraries & -- \\
\hline 15 & Pekin University Library & -- \\
\hline 16 & Pennsylvania State University Library & m.psu.edu/library/ \\
\hline 17 & * Princeton University Library & library.princeton.edu/ \\
\hline 18 & Purdue University & -- \\
\hline 19 & Seoul National University Libraries & m.lib.snu.ac.kr \\
\hline 20 & Stanford University Libraries & -- \\
\hline 21 & Swiss Federal Institute of Technology Zurich Library & library.ethz.ch/mobile/ \\
\hline 22 & Texas A\&M University Libraries & m.tamu.edu \\
\hline 23 & Tsinghua University Library & -- \\
\hline 24 & University College London Library & ucl.ac.uk/isd/students/mobile/ucl-go \\
\hline 25 & University of Arizona Libraries & m.library.arizona.edu/ \\
\hline 26 & * University of British Columbia Library & library.ubc.ca/ \\
\hline 27 & University of California Berkeley Libraries & mobile.lib.berkeley.edu \\
\hline 28 & University of California Davis Library & lib.ucdavis.edu/m/ \\
\hline 29 & University of California Los Angeles UCLA Library & m.library.ucla.edu \\
\hline 30 & University of California San Diego Library & libraries.ucsd.edu/m/ \\
\hline 31 & University of Cambridge Libraries & lib.cam.ac.uk/mob \\
\hline 32 & University of Chicago Library & mobile.lib.uchicago.edu/ \\
\hline 33 & University of Florida Libraries & uflib.ufl.edu/mobile2/ \\
\hline 34 & University of Helsinki & hulib.hulib.helsinki.fi/mobiili \\
\hline 35 & University of Illinois Urbana Champaign Library & m.library.illinois.edu/ \\
\hline 36 & University of Maryland Libraries & m.lib.umd.edu \\
\hline 37 & University of Michigan Libraries & m.lib.umich.edu/ \\
\hline 38 & University of Minnesota Libraries & lib.umn.edu/mobile/ \\
\hline 39 & University of North Carolina Chapel Hill Libraries & lib.unc.edu/m/ \\
\hline 40 & University of Oxford Libraries & m.ox.ac.uk \\
\hline 41 & University of Pennsylvania Libraries & library.upenn.edu/m/ \\
\hline 42 & University of Pittsburgh Library * & library.pitt.edu/ \\
\hline 43 & University of Southern California Libraries & usc.edu/libraries/mobile/ \\
\hline 44 & University of Texas Austin Libraries & lib.utexas.edu/m/ \\
\hline 45 & University of Toronto Libraries & -- \\
\hline 46 & University of Virginia Library & m.library.virginia.edu/ \\
\hline 47 & University of Washington Libraries & washington.edu/mobile/ \\
\hline 48 & University of Wisconsin Madison Libraries & m.library.wisc.edu/ \\
\hline 49 & Utrecht University Library & m.library.uu.nl \\
\hline 50 & Yale University Library & library.yale.edu/m/ \\
\hline
\end{tabular}




\begin{tabular}{|c|c|c|c|c|}
\hline \multirow{2}{*}{ UNIVERSITY } & \multicolumn{2}{|c|}{ MOBILE WEB } & \multicolumn{2}{|c|}{ APP } \\
\hline & INDEPENDENT & INTEGRATED & INDEPENDENT & INTEGRATED \\
\hline Harvard University & & - & & - \\
\hline Massachusetts Institute of Technology & & - & & - \\
\hline Stanford University & & & & \\
\hline Cornelll University & - & & & \\
\hline University of Michigan & • & & & \\
\hline University of California Berkeley & $\bullet$ & & & $\bullet$ \\
\hline Columbia University New York & & & & - \\
\hline University of Washington & - & & & - \\
\hline University of Minnesota & - & & & \\
\hline University of Pennsylvania & $\bullet$ & & & \\
\hline University of Texas Austin & - & & & \\
\hline University of Wisconsin Madison & - & & & \\
\hline Pennsylvania State University & - & & & \\
\hline University of California Los Angeles UCLA & - & & & - \\
\hline University of Toronto & & & & - \\
\hline Yale University & - & & & \\
\hline University of Oxford & & - & & - \\
\hline University of Cambridge & - & & & - \\
\hline Purdue University & & & & \\
\hline Texas A\&M University & - & & & - \\
\hline University of British Columbia & - & & & \\
\hline University of Illinois Urbana Champaign & - & & & - \\
\hline Michigan State University & - & & & \\
\hline New York University & & & & \\
\hline Johns Hopkins University & - & & & \\
\hline University of Florida & - & & & \\
\hline Princeton University & - & - & & \\
\hline Swiss Federal Institute of Technology Zurich & $\bullet$ & & & \\
\hline Universidade de Sao Paulo USP & & & & \\
\hline Duke University & $\bullet$ & & & \\
\hline University of California San Diego & - & - & & \\
\hline California Institute of Technology Caltech & - & & & \\
\hline University of Maryland & - & & & \\
\hline Seoul National University & - & & & \\
\hline National Taiwan University & & & & \\
\hline University of North Carolina Chapel Hill & $\bullet$ & & & \\
\hline Pekin University & & & & \\
\hline University College London & & & & - \\
\hline University of Chicago & - & & & - \\
\hline University of Pittsburgh & - & - & & \\
\hline Utrecht University & - & & - & \\
\hline Ohio State University & & & & - \\
\hline Carnegie Mellon University & $\bullet$ & & & \\
\hline University of Arizona & - & & & \\
\hline University of Helsinki & - & & & \\
\hline University of Virginia & - & & & \\
\hline Georgia Institute of Technology & - & & & \\
\hline Tsinghua University China & & & & \\
\hline University of Southern California & $\bullet$ & $\bullet$ & $\bullet$ & \\
\hline University of California Davis & $\bullet$ & & & \\
\hline
\end{tabular}


Appendix D. Evaluation of services according to University

\begin{tabular}{|c|c|c|c|c|c|c|c|c|c|c|c|c|c|c|c|c|}
\hline UNIVERSITY & TYPE & 01 & 02 & 03 & 04 & 05 & 06 & 07 & 08 & 09 & 10 & 11 & 12 & 13 & 14 & SCORE \\
\hline \multirow[t]{2}{*}{ Harvard University } & App & $x$ & $x$ & $x$ & $x$ & $x$ & $x$ & $x$ & & & & $x$ & $x$ & & & 9 \\
\hline & Mobile web & $x$ & $x$ & $x$ & $x$ & $x$ & $x$ & $x$ & & & & $x$ & $x$ & & & 9 \\
\hline \multirow[t]{2}{*}{ MIT } & App & $x$ & & $x$ & $x$ & $x$ & $x$ & $x$ & & $x$ & & $x$ & & $x$ & & 9 \\
\hline & Mobile web & $x$ & & $x$ & $x$ & $x$ & $x$ & $x$ & & $x$ & & $x$ & & $x$ & & 9 \\
\hline \multicolumn{17}{|l|}{ Stanford University } \\
\hline Cornell University & Mobile web & $x$ & $x$ & $x$ & $x$ & $x$ & $x$ & $x$ & & & $x$ & $x$ & & & $x$ & 10 \\
\hline University of Michigan & Mobile web & & & $x$ & $x$ & $x$ & $x$ & $\mathrm{x}$ & & & & $x$ & $x$ & & & 7 \\
\hline \multirow[t]{2}{*}{ University of California-Berkeley } & App & $x$ & $x$ & $x$ & $x$ & $x$ & $x$ & $x$ & & & & $x$ & & & & 8 \\
\hline & Mobile web & $x$ & $\mathrm{x}$ & $x$ & $\mathrm{x}$ & $\mathrm{x}$ & $\mathrm{x}$ & $\mathrm{x}$ & & & & $\mathrm{x}$ & & & & 8 \\
\hline Columbia University New York & App & $x$ & & $x$ & $\mathrm{x}$ & & $\mathrm{x}$ & $\mathrm{x}$ & & & & $x$ & & & $x$ & 7 \\
\hline \multirow[t]{2}{*}{ University of Washington } & App & $\mathrm{x}$ & $\mathrm{x}$ & $x$ & $\mathrm{x}$ & $\mathrm{x}$ & $\mathrm{x}$ & $\mathrm{x}$ & $x$ & $\mathrm{x}$ & $\mathrm{x}$ & & $x$ & $\mathrm{x}$ & $x$ & 13 \\
\hline & Web responsive & $x$ & $x$ & $x$ & $x$ & $\mathrm{x}$ & $x$ & $\mathrm{x}$ & $x$ & $x$ & $\mathrm{x}$ & & $x$ & $\mathrm{x}$ & $x$ & 13 \\
\hline University of Minnesota & Web responsive & $\mathrm{x}$ & $x$ & $x$ & $\mathrm{x}$ & $\mathrm{x}$ & $\mathrm{x}$ & $\mathrm{x}$ & $x$ & $\mathrm{x}$ & $\mathrm{x}$ & $x$ & $x$ & & $\mathrm{x}$ & 13 \\
\hline University of Pennsylvania & Mobile web & $x$ & $x$ & $x$ & $x$ & $x$ & $x$ & $\mathrm{x}$ & & & & & $x$ & & & 8 \\
\hline University of Texas Austin & Mobile web & $x$ & & $x$ & $\mathrm{x}$ & $x$ & $x$ & & & & & & $x$ & $\mathrm{x}$ & & 7 \\
\hline University of Wisconsin Madison & Mobile web & $x$ & $x$ & $x$ & $x$ & & $x$ & $x$ & & $x$ & & $x$ & $x$ & $x$ & $x$ & 11 \\
\hline Pennsylvania State University & Mobile web & & & $x$ & $x$ & $x$ & & & & $x$ & $x$ & & $x$ & & & 6 \\
\hline \multirow[t]{2}{*}{ University of California Los Angeles UCLA } & App & $x$ & & $\mathrm{x}$ & & $x$ & $x$ & & & & $x$ & $x$ & & & & 6 \\
\hline & Mobile web & $\mathrm{x}$ & & $x$ & & $\mathrm{x}$ & $\mathrm{x}$ & & & & $\mathrm{x}$ & $\mathrm{x}$ & & & & 6 \\
\hline University of Toronto & App & $\mathrm{x}$ & & $x$ & $\mathrm{x}$ & $\mathrm{x}$ & & $x$ & $x$ & & & $x$ & & & & 7 \\
\hline Yale University & Mobile web & $x$ & $x$ & $x$ & $x$ & & $x$ & $\mathrm{x}$ & & $\mathrm{x}$ & & $x$ & $x$ & & $x$ & 10 \\
\hline \multirow[t]{2}{*}{ University of Oxford } & App & $x$ & & $x$ & $\mathrm{x}$ & & & & & & & $x$ & & & & 4 \\
\hline & Mobile web & & & $x$ & & & & & & $x$ & & & & & & 2 \\
\hline \multirow[t]{2}{*}{ University of Cambridge } & App & $\mathrm{x}$ & & $x$ & & & & & $\mathrm{x}$ & $x$ & & $x$ & & & & 5 \\
\hline & Mobile web & $\mathrm{x}$ & & $x$ & & & & & $\mathrm{x}$ & $x$ & & $\mathrm{x}$ & & & & 5 \\
\hline \multicolumn{17}{|l|}{ Purdue University } \\
\hline \multirow[t]{2}{*}{ Texas A\&M University } & App & $\mathrm{x}$ & & & $\mathrm{x}$ & $x$ & $\mathrm{x}$ & & & & & $\mathrm{x}$ & $\mathrm{x}$ & & $x$ & 7 \\
\hline & Mobile web & $x$ & & & $x$ & $x$ & $x$ & & & & & $x$ & $x$ & & $x$ & 7 \\
\hline University of British Columbia & Mobile web & $\mathrm{x}$ & & $\mathrm{x}$ & $\mathrm{x}$ & $x$ & $\mathrm{x}$ & $x$ & $\mathrm{x}$ & $x$ & & $\mathrm{x}$ & $\mathrm{x}$ & & $x$ & 11 \\
\hline \multirow[t]{2}{*}{ University of Illinois Urbana Champaign } & App & $x$ & & $x$ & $\mathrm{x}$ & $\mathrm{x}$ & $\mathrm{x}$ & & $\mathrm{x}$ & $\mathrm{x}$ & & $x$ & $x$ & & $\mathrm{x}$ & 10 \\
\hline & Mobile web & $\mathrm{x}$ & & $\mathrm{x}$ & $\mathrm{x}$ & $\mathrm{x}$ & $\mathrm{x}$ & & $x$ & $\mathrm{x}$ & & $\mathrm{x}$ & $x$ & & $x$ & 10 \\
\hline Michigan State University & Mobile web & $\mathrm{x}$ & $x$ & $x$ & $\mathrm{x}$ & $\mathrm{x}$ & $\mathrm{x}$ & $\mathrm{x}$ & & & & $\mathrm{x}$ & $x$ & & & 9 \\
\hline \multicolumn{17}{|l|}{ New York University } \\
\hline Johns Hopkins University & Mobile web & $x$ & & $x$ & $\mathrm{x}$ & & & & & & & $\mathrm{x}$ & $\mathrm{x}$ & & $\mathrm{x}$ & 6 \\
\hline
\end{tabular}




\begin{tabular}{|c|c|c|c|c|c|c|c|c|c|c|c|c|c|c|c|c|}
\hline UNIVERSITY & TYPE & 01 & 02 & 03 & 04 & 05 & 06 & 07 & 08 & 09 & 10 & 11 & 12 & 13 & 14 & SCORE \\
\hline University of Florida & Mobile web & $\mathrm{x}$ & & $\mathrm{x}$ & & $\mathrm{x}$ & & $\mathrm{x}$ & $x$ & & $\mathrm{x}$ & & $\mathrm{x}$ & & & 7 \\
\hline Princeton University & Mobile web & $\mathrm{x}$ & $\mathrm{x}$ & $\mathrm{x}$ & $\mathrm{x}$ & & $\mathrm{x}$ & $\mathrm{x}$ & $\mathrm{x}$ & & & $\mathrm{x}$ & $\mathrm{x}$ & & & 9 \\
\hline Swiss Federal Institute of Technology Zurich & Mobile web & $x$ & & $\mathrm{x}$ & $\mathrm{x}$ & $x$ & & $\mathrm{x}$ & & $x$ & & $x$ & $x$ & & & 8 \\
\hline \multicolumn{17}{|l|}{ Universidade de Sao Paulo USP } \\
\hline Duke University & Mobile web & $\mathrm{x}$ & $\mathrm{x}$ & $x$ & $x$ & & $\mathrm{x}$ & $\mathrm{x}$ & & $x$ & & $x$ & & $\mathrm{x}$ & & 9 \\
\hline University of California San Diego & Mobile web & $\mathrm{x}$ & & $\mathrm{x}$ & $\mathrm{x}$ & $\mathrm{x}$ & $\mathrm{x}$ & & & & $\mathrm{x}$ & $\mathrm{x}$ & $\mathrm{x}$ & & & 8 \\
\hline California Institute of Technology & Mobile web & $x$ & & $x$ & $x$ & $x$ & $x$ & $\mathrm{x}$ & & & & $x$ & $x$ & & & 8 \\
\hline University of Maryland & Mobile web & $\mathrm{x}$ & $\mathrm{x}$ & $x$ & $x$ & $x$ & $\mathrm{x}$ & & & $x$ & $x$ & $x$ & $x$ & & $\mathrm{x}$ & 11 \\
\hline Seoul National University & Mobile web & $x$ & & $x$ & $x$ & & & $\mathrm{x}$ & & $x$ & & $x$ & $\mathrm{x}$ & & $\mathrm{x}$ & 8 \\
\hline \multirow[t]{2}{*}{ National Taiwan University } & App & & & & & & & & & & & & & & & \\
\hline & Mobile web & & & & & & & & & & & & & & & \\
\hline University of North Carolina Chapel Hill & Mobile web & $x$ & $\mathrm{x}$ & & $x$ & & & $\mathrm{x}$ & $x$ & $x$ & & & $\mathrm{x}$ & & $\mathrm{x}$ & 8 \\
\hline \multicolumn{17}{|l|}{ Pekin University } \\
\hline University College London & App & & $\mathrm{x}$ & & & & & & $\mathrm{x}$ & $x$ & & $\mathrm{x}$ & & & & 4 \\
\hline \multirow[t]{2}{*}{ University of Chicago } & App & $\mathrm{x}$ & & $\mathrm{x}$ & & $\mathrm{x}$ & $\mathrm{x}$ & & & & $\mathrm{x}$ & & & & $\mathrm{x}$ & 6 \\
\hline & Mobile web & $\mathrm{x}$ & & $\mathrm{x}$ & & $\mathrm{x}$ & $\mathrm{x}$ & & & & $x$ & & & & $\mathrm{x}$ & 6 \\
\hline University of Pittsburgh & Mobile web & $\mathrm{x}$ & $x$ & $x$ & $x$ & & $x$ & & & & & & $x$ & & & 6 \\
\hline \multirow[t]{2}{*}{ Utrecht University } & App & & & & & & & & $x$ & $x$ & & & & $\mathrm{x}$ & & 3 \\
\hline & Mobile web & $x$ & & $x$ & $x$ & $x$ & & $x$ & $\mathrm{x}$ & & $x$ & & $x$ & $x$ & & 9 \\
\hline Ohio State University & App & $\mathrm{x}$ & & $x$ & & & & & & & & $x$ & & & & 3 \\
\hline Carnegie Mellon University & Mobile web & $x$ & & $x$ & $x$ & $x$ & & & & & & $x$ & & & & 5 \\
\hline University of Arizona & Mobile web & $x$ & $x$ & $x$ & $x$ & $x$ & $x$ & & & & & $x$ & & & $x$ & 8 \\
\hline University of Helsinki & Mobile web & $x$ & & $x$ & $x$ & $x$ & & $x$ & & & & $x$ & & & & 6 \\
\hline University of Virginia & Mobile web & $x$ & $x$ & $x$ & $x$ & & $x$ & $x$ & & $\mathrm{x}$ & & $x$ & $x$ & & & 9 \\
\hline Georgia Institute of Technology & Mobile web & $x$ & & $x$ & $\mathrm{x}$ & $x$ & & $x$ & & & $x$ & & & & & 6 \\
\hline \multicolumn{17}{|l|}{ Tsinghua University China } \\
\hline \multirow[t]{2}{*}{ University of Southern California } & App & & & & $x$ & $x$ & & $\mathrm{x}$ & & $\mathrm{x}$ & & & & & & 4 \\
\hline & Mobile web & $x$ & $\mathrm{x}$ & $x$ & $x$ & $x$ & $x$ & $\mathrm{x}$ & $x$ & $\mathrm{x}$ & $x$ & $x$ & & & $\mathrm{x}$ & 12 \\
\hline University of California Davis & Mobile web & $\mathrm{x}$ & $x$ & $x$ & & $x$ & $x$ & & & $\mathrm{x}$ & & $\mathrm{x}$ & & & & 7 \\
\hline
\end{tabular}

01: Library Hours; 02: Library directory; 03: Library catalog; 04: Contact us; 05: Main Library; 06: Ask a librarian; 07: Library news; 08: Renew material; 09: My account; 10: Computer availability; 11: Floor plans/ maps; 12: Databases; 13: Loan periods; 14: Reserve studies. 
Appendix E. Academic library ranking according to app services deployed

\begin{tabular}{rlc}
\hline Rank & University & Score \\
\hline 1 & University of Washington & $\mathbf{1 3}$ \\
2 & University of Illinois Urbana Champaign & $\mathbf{1 0}$ \\
3 & Harvard University & $\mathbf{9}$ \\
3 & Massachusetts Institute of Technology & $\mathbf{9}$ \\
5 & University of California Berkeley & $\mathbf{8}$ \\
6 & Columbia University New York & $\mathbf{7}$ \\
6 & Texas A\&M University & $\mathbf{7}$ \\
6 & University of Toronto & $\mathbf{7}$ \\
9 & University of California Los Angeles UCLA & $\mathbf{6}$ \\
9 & University of Chicago & $\mathbf{6}$ \\
11 & University of Cambridge & $\mathbf{5}$ \\
12 & University College London & $\mathbf{4}$ \\
12 & University of Oxford & $\mathbf{4}$ \\
12 & University of Southern California & $\mathbf{4}$ \\
15 & Ohio State University & $\mathbf{3}$ \\
15 & Utrecht University & $\mathbf{3}$ \\
17 & National Taiwan University & -- \\
\hline
\end{tabular}


Appendix F. Academic library ranking according to mobile web services deployed

\begin{tabular}{|c|c|c|}
\hline $\mathbf{R}$ & UNIVERSITY & M-WEB SCORE \\
\hline 1 & University of Minnesota & 13 \\
\hline 1 & University of Washington & 13 \\
\hline 3 & University of Southern California & 12 \\
\hline 4 & University of British Columbia & 11 \\
\hline 4 & University of Maryland & 11 \\
\hline 4 & University of Wisconsin Madison & 11 \\
\hline 7 & Cornell University & 10 \\
\hline 7 & University of Illinois Urbana Champaign & 10 \\
\hline 7 & Yale University & 10 \\
\hline 10 & Duke University & 9 \\
\hline 10 & Harvard University & 9 \\
\hline 10 & Massachusetts Institute of Technology & 9 \\
\hline 10 & Michigan State University & 9 \\
\hline 10 & Princeton University & 9 \\
\hline 10 & University of Virginia & 9 \\
\hline 10 & Utrecht University & 9 \\
\hline 17 & California Institute of Technology Caltech & 8 \\
\hline 17 & Swiss Federal Institute of Technology Zurich & 8 \\
\hline 17 & University of Arizona & 8 \\
\hline 17 & University of California Berkeley & 8 \\
\hline 17 & University of California San Diego & 8 \\
\hline 17 & University of North Carolina Chapel Hill & 8 \\
\hline 17 & University of Pennsylvania & 8 \\
\hline 24 & Seoul National University & 7 \\
\hline 24 & Texas A\&M University & 7 \\
\hline 24 & University of California Davis & 7 \\
\hline 24 & University of Florida & 7 \\
\hline 24 & University of Michigan & 7 \\
\hline 24 & University of Texas Austin & 7 \\
\hline 30 & Georgia Institute of Technology & 6 \\
\hline 30 & Johns Hopkins University & 6 \\
\hline 30 & Pennsylvania State University & 6 \\
\hline 30 & University of California Los Angeles UCLA & 6 \\
\hline 30 & University of Chicago & 6 \\
\hline 30 & University of Helsinki & 6 \\
\hline 30 & University of Pittsburgh & 6 \\
\hline 37 & Carnegie Mellon University & 5 \\
\hline 37 & University of Cambridge & 5 \\
\hline 39 & University of Oxford & 2 \\
\hline 40 & National Taiwan University & -- \\
\hline
\end{tabular}

